\title{
Did South America foster European football?: transnational influences on the continentalization of FIFA and the creation of UEFA, 1926-1959
}

\section{Philippe Vonnard \& Grégory Quin}

To cite this article: Philippe Vonnard \& Grégory Quin (2016): Did South America foster European football?: transnational influences on the continentalization of FIFA and the creation of UEFA, 1926-1959, Sport in Society, DOI: 10.1080/17430437.2016.1221208

To link to this article: http://dx.doi.org/10.1080/17430437.2016.1221208

册 Published online: 22 Aug 2016.

Submit your article to this journal $[\pi$

Џll Article views: 28

Q View related articles $₫$

View Crossmark data 


\title{
Did South America foster European football?: transnational influences on the continentalization of FIFA and the creation of UEFA, 1926-1959
}

\author{
Philippe Vonnard and Grégory Quin \\ Institute of Sport Studies, University of Lausanne, Lausanne, Switzerland
}

\begin{abstract}
UEFA was formed in Basel in June 1954, and began to take control of European football soon after its inception. It was an exceptional PanEuropean organization in the context of the ongoing cold war since it almost exclusively granted memberships to football associations from Eastern Europe and the Iberian Peninsula, managing to tower above divisive ideological antagonisms. This article approaches the history of UEFA's establishment from a global history perspective. It highlights the hitherto overlooked impact of FIFA's dialogues with the South American football confederation and national associations on the creation of UEFA as a representative European institution. Firstly, it traces the South American demand for more influence on the governance of world football (especially within FIFA's committees) in the inte-rwar years, a situation that created a rift between South American and European representatives in FIFA. This confrontation arguably'helped' the European associations to self-integrate, leaving behind their internal differences, in order to restore the hegemony they used to exercise inside FIFA before the South American dissent. Secondly, it emphasizes the role played by the South American confederation in the reorganization of FIFA in the early 1950s. Thirdly, it briefly focuses on how the South American confederation initially served as a model for the activities of UEFA.
\end{abstract}

\section{Introduction}

In June 1954, 28 national football associations from across Europe gathered in Basel to create a continental organization. This was a direct response to the change in the statutes of the Fédération Internationale de Football Association (FIFA) in 1953 which required member associations to form continental organizations, each of which would in turn elect one representative to the FIFA Executive Committee (FIFA, FIFA Statutes, edition of 1954). Thus, and contrary to prevalent ideas, the organization's first goal was not to start new European competitions but rather to create an interest group within FIFA. In October 1954, the 'Groupement' was named as the Union of European Football Associations (UEFA). Its first official General Assembly was held in Vienna in March 1955. From 1955 to 1960, UEFA 
increased its prerogatives, created a number of competitions (Vonnard 2014), and began to control broadcasting (Mittag and Nieland 2013) and other aspects of European football, for example youth football (Marston 2015). At the end of the decade, the organization had successfully connected most of the European football associations and established itself as one of the foremost powerbrokers of football's politics.

Taking into consideration the context of the process of European integration postSecond World War, UEFA's creation was not an isolated occurrence. Since the beginning of the 1950s, Pan-European political, economic, scientific and cultural initiatives as diverse as the Council of Europe, the European Economic Community, the European Free Trade Association, the European Broadcasting Union, the European Community of Writers (Racine 2008) and the European Confederation of Post Office (Laborie 2010) came up. The French historian concept of 'Europe-organisation' describes perfectly the development of a 'European' way in the creation of organizations. UEFA's structure was nevertheless an exception because contrary to most other continental organizations it did not exclude East European countries, somehow rising above cold war antagonisms (Loth 2004). Moreover, it included also the Iberian countries, Spain and Portugal, which were then blacklisted from international competitions due to their dictatorial governance (Cavallaro 2009). In 1955, it accepted Turkey's request for membership, though formal admission was granted only in the beginning of 1960s (Senyuva and Tunç 2015). Therefore, from a geographical point of view (Péchoux 2004), UEFA constituted the most pervasive European organization in the 1950s. This built-in internationalist outlook was arguably a result of long-term negotiations among football associations from Europe and South America, leading to UEFA's formation.

Influenced by the application of global history methods in sport studies (Collins 2015; Gleaves and Hunt 2015; Klein 2007; Singaravélou and Sorez 2010; Taylor 2013), especially in football (Giulianotti and Roberston 2009; Grainey 2012; Tiesler and Coelho 2008), this article analyses the global context of UEFA's creation, highlighting South American influence on this European organization. None of the studies on the early years of UEFA (Archambault 2012; Barcelo 2004; Mittag 2015) mention this connection, and only two contributions have so far focused on the influence of non-European administrators on the structural hierarchy of UEFA. Sudgen and Tomlinson (1997) wrote briefly about the 'continentalization' of FIFA but lack of documents (particularly at the FIFA archives) limited their understanding of the connection between South American and European football administrators. Dietschy's (2013) article on FIFA's globalization from 1920 to 1970 offers interesting insights into the intercontinental development of FIFA, but mentions only peripherally the establishment of UEFA.

The article is structured around three connected developments in world football administration in the first half of the twentieth century. Firstly, it traces the South American demand for more influence on the governance of world football (especially within FIFA's committees) in the inter-war years, a situation that created a rift between South American and European representatives in FIFA. This confrontation arguably 'helped' the European associations to self-integrate, leaving behind their internal differences, in order to restore the hegemony they used to exercise inside FIFA before the South American dissent. Secondly, it emphasizes the role played by the South American confederation in the reorganization of FIFA in the early 1950s. Thirdly, it briefly focuses on how the South American confederation initially served as a model for the activities of UEFA. 
Our research is primarily based on documents from the FIFA archives, in particular the minutes of the Executive and Emergency Committees and the Congresses, as well as correspondences (of the presidents and between FIFA and UEFA, the South American and confederation and other national associations) and documents about the reorganization of FIFA between 1950 and 1953. Archives of the East German football federation (GDR) yielded documents of the creation of UEFA. Moreover, it is possible to find in the FIFACONMEBOL correspondences documents from the former South American confederation (mostly minutes of ordinary and extraordinary congresses, some minutes of the Executive Committee, and annual reports). Furthermore, materials drawn from the French journals L'Equipe, Football, France Football have helped to fill up the gaps.

This article is a first step towards more in-depth future research on this topic. In this sense, it could be really interesting to use materials from the archives of the South American confederation that would complement the European documents about the connections among the new generation of FIFA/UEFA administrators in the beginning of 1950s. A more exhaustive work at the CONMEBOL's archives (in our knowledge, no academic research in English, French, German, Portuguese or Spanish have used this material) could help broaden our understanding, an effort we plan to undertake in the future.

\section{South American intervention and internationalization of FIFA in the inter- war period}

Football developed rapidly across Europe during the first quarter of the twentieth century, supported by the newly established FIFA (Eisenberg et al. 2004). The game spread across South America around the same time (Archambault 2014; L'Hoeste, McKee Irwin, and Poblete 2015). Started largely by the upper middle classes in Brazil (Davies 2000; Fontes and de Hollandia 2014), Argentina (Alabarces 2002) and Uruguay (Armus and Rinke 2014), it was transmitted to people from the other countries, and around 1910-1920 underwent a crucial democratization process (Mason 1995). A national football association was founded in Argentina in the late nineteenth century (Hémeury 2014), which was remarkably one of the first to have been established outside Great Britain. In the following decades came up other national associations, notably in Brazil and Uruguay, and in 1915 a confederation of South American associations was established by these three countries. During the 1920s, countries such as Chile, Bolivia and Peru joined the organization, following possibly a broader contemporary effort of continental cooperation built around culture and science (Dumont 2009).

The Confederation started a competition for South American nations in 1916 - the Copa America - which was the first football tournament organized on a continental scale. So, while European teams played in regional competitions such as the International Cup (Quin 2013) or the Balkan Cup (Breuil and Pompiliu-Nicolae 2015), South America had taken the sport's globalization a step forward. Moreover, the skill level of South American players created an excellent impression on the Europeans, which was strengthened by Uruguay winning the Olympic titles in 1924 and 1928, which was considered the most important global football competition before the World Cup began in 1930. The play of the 'Celeste' startled European journalists, who began portraying South American football as otherworldly from around this time. 
During the 1920s, countries such as Bolivia, Ecuador and Paraguay joined FIFA. At the same time, associations from Asia and Africa started appealing for FIFA membership (Dietschy 2010; Goldblatt 2006). However, membership to the FIFA Executive Committee remained a privilege of Europeans. In 1924, Wali Pasha from Egypt unsuccessfully tried to be elected to the Executive Committee (FIFA, Congress, May 26-28, 1924). Thereafter, FIFA started to consider granting more privilege to extra-European federations. At the 1927 Congress in Helsinki, an American delegate jokingly proposed that in 50 years, which meant the 1976 Congress, the conference should be held in his country (FIFA, Congress, June $3-5,1927)$. Beyond the joke and the little laughter it might have generated, the statement indicates the feeling of marginalization among non-European members.

The pressure from non-European countries increased with every passing year, prompting some of the Executive Committee members to ponder their demand for inclusion, which is documented in FIFA statutes from the late-1920s. A new position of the councillor - one for each continent - was created to facilitate the Secretariat's contact with national bodies (FIFA, FIFA Statutes, edition of 1929). This hardly increased participation of the nonEuropean members as the councillors were not selected from the region they represented but from Europe, who were often too busy with their day jobs to manage football governance.

In 1927, a new step was taken towards globalizing the administration of international football as Enrique Buero from Uruguay was appointed as the first non-European member of the Executive Committee. Similar to the case of councillors, the choice of Buero too was a ploy for Europeans to maintain control. Buero was not a football administrator, but a diplomat posted in Belgium, and later in England. He came from a highly Westernized family; spoke fluently several European languages, and his brother worked as a jurist in the League of Nations in the inter-war years. Initially he found it difficult to communicate with the South American confederation since he was to them an outsider. But putting the contacts made through diplomatic career to good use, he campaigned for organizing the World cup in his country and succeeded.

The European football associations were in full control of FIFA at the end of the 1920s, which began to change following the 1930 World Cup. Members of FIFA's Executive Committee, such as Rodolphe Seeldrayers or Jules Rimet, were very impressed with the tournament's organization, the architecture of huge stadiums such as the Centenarios in Montevideo, the enthusiasm of local fans, and of course the quality of football in the region. Football was no longer a decidedly European game. The South American federation was not too happy with the lack of interest among European countries to travel to the other hemisphere. Even as a majority of FIFA members had voted at the 1929 Congress for Uruguay to host the first World Cup (FIFA, Congress, May 17-18, 1929), only four European countries (Belgium, France, Romania, Yugoslavia) decided to participate in the tournament. The strongest teams - except for the British associations, which had withdrawn from FIFA in 1928 (Beck 2000) - from Central Europe (Austria, Hungaria, Czechoslovakia) and Italy decided not to go, practically 'boycotting' the event. A number of football administrators saw no sense in travelling so far as Uruguay. A few among them such as Hugo Meisl or Giovanni Mauro preferred to develop a European championship (Quin 2013). Ironically, two weeks before the World Cup, the main Central European countries played in Geneva an international tournament called 'La Coupe des nations' which was widely covered by the European press. 
This apathy and counter-event caused tension between South America and Europe. Some months before the tournament, the French newspaper Football had indicated a potential South American boycott against European teams which declined to travel (Football, May 30, 1930). This was a likely threat given the concurrent efforts of South American governments to create close diplomatic ties with one another (Dumont 2012), helped by a favourable economic context (Diaz Alejandro 1984; Thorp 1994). This context allowed progressively the emancipation of South American countries, both politically and economically, from Europe (Compagnon 2013). But the proponents of South American cooperation failed to notice the potential of the football field. Following the dramatic jingoism on display at the 1930 World Cup final, Argentina and Uruguay refused to face off for five years (Dietschy, Gastaud, and Mourlane 2006). No Copa America event was organized in the meantime. This friction also delayed the development of a South American stronghold within FIFA. In the 1930s they demanded more recognition and campaigned for a quota within the Executive Committee, leading to a confrontation with European countries. Only Brazil and Argentina participated in the second World Cup in Italy in 1934, which revealed the intercontinental tension. However, internal troubles weakened their collective voice.

The South America-Europe conflict reached a peak during the second round of the Olympics football event in 1936, when the Jury of the tournament overturned Peru's victory over Austria. The officials awarded the match to Austria on the pretext of the presence of Peruvian fans on the field during the second half of the extra time, some of whom reportedly injured Austrian players (Dietschy 2013). At the 1936 FIFA Congress, the South American associations demanded a replay of the game. The Executive Committee did not relent, which raised a storm of protests from the South American delegates (FIFA, Congress, August 13-14, 1936). The decision to give the third World Cup to France despite the candidacy of Argentina was seen as another Eurocentric imposition. South American members thought it was logical for the next tournament to be held on their continent. The next Extraordinary Congress of the South American confederation decided to increase group cooperation to creatively posit itself as a pressure group inside FIFA, but their internal differences once again proved to be inimical. Countries such as Chile and Peru suggested withdrawal from FIFA, but no unanimity could be reached (FIFA, Letter from I. Schricker to the Executive Committee, November 21, 1936). Other countries differed, and Argentina and Brazil felt that withdrawing from FIFA would be too extreme a step. Finally it was proposed, in terms of the Santiago Agreement, that they would push for a non-European member to be appointed in the future Jury of Tournaments. Furthermore, they wanted a fixed place for South America inside FIFA's Executive Committee. A year later, revealing this lack of unity, Argentina left the Confederation. At the 1938 FIFA Congress, the Brazilian delegate indicated that even though his country was a member of the Confederation he 'did not recognize any restriction and any intervention from the South American Confederation on his own affair and that he wanted to maintain his direct relations with FIFA' (FIFA, Congress, March 5-6, 1938).

Despite the conflict that threatened to pull the South American confederation apart, European football administrators considered their demands. The changed attitude was fostered by the increasing importance of non-European countries inside FIFA. Moreover, a confederation in Central America was created in the late-1930s by Hector Beeche (Dietschy 2013), which sided with South America. FIFA acceded to both of the demands for a fixed place on the Committee and a reserved place in the Jury of the Tournament. In 1939, the president Jules Rimet travelled to South America, met football administrators and tried to 
ease the tension. The trip was deemed to be successful as the South American members decided to cancel the Santiago Agreement (FIFA, Letter from I. Schricker to the Executive Committee, April 21, 1939). Although this step was nothing more than short-term appeasement, FIFA's structure underwent significant changes in the next decade, under the influence of the Second World War and the strengthening of a South American continental voice in football.

\section{FIFA's continentalization as a new step in the internationalization of football}

FIFA functioned in a reduced capacity through the Second World War, especially after 1942 (Dietschy 2006). Wartime emergencies and restrictions made it difficult for the secretary, Ivo Schricker, to maintain correspondence with South American federations. Additionally, the South American member of the Executive Committee, Luis Dupuy, had to return to his country in 1943 (FIFA, Letter from I. Schricker to E. Borrero, March 17, 1943). It was an important loss for Schricker because Dupuy was his link with South America and also a trusted companion. Furthermore, Dupuy was an enterprising administrator, always on the lookout for initiating meaningful discussions rather than just differing with FIFA's opinion. At the same time, the South American Confederation took some crucial measures to consolidate understanding among members and also to create a common voice inside FIFA. Luis Valenzuela, the new president appointed in 1939, was apparently a strong advocate of South American football. He defended his position inside FIFA for 15 years and tried to give more power to his Confederation. Under his influence, new connections between associations of the continent seemed to be created. An important step was taken when Argentina returned to the organization in 1941. Then, in 1942, they discussed the idea to celebrate a 'day for South American football', to symbolically reinforce fraternity among the associations. These actions corresponded to the emerging Pan-Americanism that helped to interconnect countries in the region, especially within South America (Compagnon 2015).

Moreover, the Confederation decided to demand more autonomy within FIFA. Firstly, in 1941, it expressed interest to host the next World cup. Secondly, it decided to send to Zurich only half of the amount of financial benefit from the international matches played in South America (Homburg 2008). At a time when football war-torn Europe hardly yielded profit, the FIFA secretary Ivo Schricker did not take kindly to this decision. Thirdly, in 1945, a letter undersigned by Augustin Matienzo, the new delegate of the South American Confederation in FIFA's Executive Committee, proposed to organize the next FIFA Congress in 1946 in Montevideo. He wrote that the Executive Committee was now illegitimate, after its mandate was finished in 1942 (FIFA, Letter from A. Matienzo to I. Schricker, July 23, 1945). This action shows that South America now directly challenged FIFA's singular control over football's international governance. The Executive Committee transferred to the delegates of the next Congress the responsibility to take a decision about these demands. In the absence of a Congress since 1938, the mandate remained inconclusive. Probably to fight against this takeover attempt, the Executive Committee decided to organize the next Congress in Luxembourg, the city chosen in 1938. Situated in the middle of Europe, it was not a favourable location for South American delegates, who wanted Lisbon to be the venue. The choice of Luxembourg, however, did not deter them from sending delegates to the meeting. 
Tension between Europe and South America increased as in the following years South American members asked for more legitimacy inside FIFA. The latter wanted to decentralize FIFA's solitary authority over world football by giving more power and influence to each continental segment of the governing body. This reflected a paradigm shift in global cooperation post-Second World War, characterized by, as Eric Helleiner (2014) has showed, alliance among non-European countries, and new international organizations involving the United States and countries in Asia or South America. The European colonial powers lost their political superiority after the War; maximum global influence was now commanded by the United States of America and the Soviet Union. Even if the political bipolarity mattered little to football governance (Kowalski and Porter 2007), as football was not a major interest for the two superpowers, this situation impinged the European dominance over football.

To be more effective inside FIFA, South America went about implementing an idea discussed in the 1930s: that of creating a Pan-American organization. Included for the first time in the new statutes of the South American Confederation in 1941, the idea took a concrete shape in 1946. In 1948, the Pan-American organization had 19 members (FIFA, 'Associations members of the [new] Pan-American confederation', March 30, 1948). Now, had all of the members decided to pursue the same goal in the inter-war years, it could have created a powerful bloc inside FIFA, putting Europeans countries under unprecedented pressure. Now was an even better time. The geopolitical consequences of the War, particularly the dispute over the status of Germany (Dichter 2013; Wahlig 2010) and Italy (Sbetti 2016), were disquieting. Moreover, Communist expansion in Central Europe created a rift between the Eastern and the Western European football associations. Between the 1946 and the 1948 Congresses, a Soviet-influenced bloc emerged inside FIFA. In the context of strong East-West confrontations, participation in sporting organizations was crucial for the Soviet Union (Parks 2007) and the United States (Gygax 2012; Rider 2011), as sport was considered by both as an arena of symbolic battle between capitalism and communism and later also as a site of the sort of diplomatic exchange not possible at political or economic summits (Dichter and Johns 2014; Malz, Rohdewald, and Wiederkehr 2007). The cold war furthered the separation, so much so that from mid-1949 to mid-1952, no games were played among European countries across the Iron Curtain and competitions such as the International Cup were stopped (France Football, April 19, 1949).

Additionally, to operationalize FIFA's decentralization, reorganization of its structure regarding the development of football itself was considered necessary. In fact, many of newly independent countries from Central America and Asia received FIFA affiliation during the 1940s and 1950s, which marked expansion of the football world. Membership grew from approximately 30 in the middle of the 1930s to more than 70 in the early 1950s, to 88 in 1955 (FIFA, Secretary Report, 1954-1955). Football reached far and wide as air travel escalated the number of international exchanges, including the organization of matches between national teams and clubs and inter-continental tournaments (such as the Copa Rio which started in 1951), and increased circulation of players and coaches (Taylor 2006).

The increase in the number of members can also be explained in terms of the ongoing decolonization of nations. Football - and more broadly sports - represented to the emergent nation-states a means to inspire national cohesion, to affirm independent national identities and also to be taken seriously internationally (Charitas 2015). That is why the countries that were still colonized, like Gold Coast, or were resisting colonial dominance, like Vietnam, asked at the beginning of the 1950s for a FIFA membership. These newcomers 
wanted more than just membership; they wanted a place within FIFA's management. For example, during an Executive Committee meeting in June 1950, Gold Coast asked FIFA to support the constitution of a new 'United African Football Association', consisting of the associations of South Africa, Ivory Coast, Gold Coast, Nigeria, Sierra Leone and Togo. The objective of this union was 'to create a closer liaison amongst the African associations, to exchange their views, to organise the payment of members' contributions, to organise regular inter-colony matches and to establish an annual inter-colony competition' (FIFA, Congress, June 22-23, 1950).

Technically Great Britain, having returned to FIFA under the leadership of the Football Association (recommended by a special commission in 1944) after the Second World War, made the first attempt to decentralize football governance (Taylor 2016). The Soviet Union, which entered the Federation in 1948, wanted the same, and received in two months a fixed position in the Executive Committee. Such expedited decision-making corresponded to a change in FIFA's organization. It also empowered the promoters of decentralization, as the two new members could be seen to have spoken for the four British associations and all the associations potentially included in the Soviet Bloc. It was argued that managing a sport so globally distributed was too difficult to be undertaken by one administrative organization, which was justified by the problems arising from the 1950's 'World Cup qualifications' in South America. Some of the groups encountered difficulties as countries such as Ecuador, Paraguay, Peru and Uruguay failed to fix dates of fixtures due to a breakdown of communication for geographical distance and political problems. As the Uruguayan government did not recognize the Peruvian one, it did not even try to negotiate dates and simply rejected every proposal. Intervention of the South American confederation proved to be futile. The FIFA secretary too was located too far to mediate. Moreover, failure to fathom the ground reality made Schricker propose unrealistic solutions which were not accepted by South American administrators. The distance between the headquarters and numerous members of the Federation - literally and figuratively - nourished the idea of the necessity of an imperative decentralization of FIFA in order to improve the management and practice of football worldwide.

All these incidents further authenticated the South American demands. At the 21st Ordinary Congress of the South American confederation held in Rio de Janeiro in May 1949, the delegates discussed a possible recast of the FIFA statutes. They talked about the Argentine association's proposal to have a more equitable distribution of continental representation within the FIFA Executive Committee. Essentially, they wanted FIFA to recognize South America by assigning it additional places within the Executive committee (FIFA, South American Confederation Congress, March-May, 1949). The one place they had negotiated seemed to be under threat as the number of FIFA members kept increasing. Indeed, since the Executive Committee members were elected by voting at the Congresses, the attendance at which had nearly doubled in the last few years, the South American confederation feared more global distribution of power and reduction of the authority it claimed. Finally, the South American members sent two proposals that were discussed during the 1950 FIFA Congress, the first to be organized outside Europe, in Rio de Janeiro during the World Cup. A change in FIFA's organization seemed necessary and a few European football administrators began to contemplate revision of its constitution. 


\section{The impact of South America on restructuring FIFA and the network of European associations after 1950}

The South American agenda was clear: divide FIFA in continental groups that would control and manage their own football spheres, instead of just electing representatives to the main FIFA committees (FIFA, Annexe to the Agenda of the 1950's FIFA Congress). The Congress commissioned a special inquiry to analyse the situation and propose possible measures. Despite the overt presence of European delegates in this new commission (only two out of seven delegates came from the South American associations), there was hope for a change. In fact, the idea to reorganize FIFA was supported by a new generation of European football administrators who were probably influenced by the organization and success of football in South America. They were Ottorino Barassi (Italy), Stanley Rous (England) and Ernst Thommen (Switzerland), who became the most important people in FIFA at the beginning of the 1950s following Schricker's retirement. The new general secretary, Kurt Gassmann, was a colleague of Thommen since the late-1930s as the former secretary of the Swiss federation (Berthoud, Quin, and Vonnard 2016), and was considered extremely reliable. Barassi and Rous were appointed as joint secretaries in the reorganization commission, a role that revealed their importance in international football. In their opinion, it was time to consider the possibility of creating continental organizations within FIFA, following the South American confederation model. In 1952, Barassi took a step forward and communicated in letters addressed to several European associations the idea to create a European organization (FIFA, Annexe of a Letter from O. Barassi to R. Seeldrayers, undated). These actors detached themselves from the old elite which was gradually phasing out of FIFA. They received a fillip when Jules Rimet retired in 1954, whose vision limited the application of the proposed changes.

However, the new elite did not aim for a quick reorganization of the Federation, but rather for a smooth transition. In this sense they agreed with a new version of FIFA, divided into continental groups with moderate power. Taking into account the Copa America tournament started by the South American Confederation, they expected to launch a PanEuropean tournament, an idea already discussed during the inter-war period, under the aegis of the proposed European continental federation. Barassi, having travelled many times to South America for work, probably had the opportunity to witness the organization of football first-hand and to converse with the presidents and secretaries of football associations, which deeply influenced his will to copy the South American model.

Yet, all European administrators did not share these ideas. That is why, during the meetings of the European associations in Zurich and Paris held in May and June 1952 respectively under the presidency of Barassi (L'Equipe, March 29, 1952), the idea of creating a European group was quickly buried. These sessions served to discuss other proposals for the reorganization of FIFA, matters which would have to be debated at the next FIFA Congress, to be organized in Helsinki a few weeks later (FIFA, FIFA Congress, July 20-23, 1952). It is important to notice that no Eastern European countries, not even Yugoslavia which was a non-aligned country and buffered Western Europe from the Soviet Bloc (Svetozar 2011), took part in the meetings. Nonparticipation had without doubt prevented the inclusion of the Soviet Union and its satellites within this new organization. The cold war still restricted exchanges in continental football. 
The decentralization debate continued in Helsinki. Several South American administrators started long discussions regarding regulatory issues (official language, correspondence), which seemed secondary to the Europeans. For the first time both the European and South American delegates showed interest in negotiating the same mandate, in contrast with the previous instances of the latter forcing the former to cede ground. It was decided to report the final decision to an Extraordinary Congress to be held in 1953. As a matter of fact, European members rejected the South American proposal about the method of electing vice-presidents. So far, vice-presidents had been elected by acclamation (without votes). That year, the South American members pitted Domingo Peluffo, an Argentinian delegate, against the current vice-president Seeldrayers, who had occupied the post for more than twenty years. This contest provoked an outcry among the European members, even though Seeldrayers was finally re-elected with a vast majority (FIFA, FIFA Congress, July 20-23, 1952).

Regarding the discussion at the Congress, José Crahay - another new-generation delegate and one of the first promoters of the idea of UEFA - wrote in the 1979 UEFA commemorative book that they 'realized that every single item in the agenda [had] been thoroughly studied and that the [South American] delegates [had] been truly appointed to defend positions frequently different from the ones supported by the Executive Committee of the FIFA' (Rothenbühler 1979). The formation of a 'South American bloc' in Helsinki impressed several European delegates and persuaded them to put up a similar pressure group in Europe as a countermeasure. In the middle of 1952, the idea to create a European 'Groupement' began to materialize, in which the attitude of the South American football members had played an important role.

In the following months, the idea to create a European organization was discussed at several levels. For example, Yugoslavia and Germany sent to the FIFA secretary a project to this direction and the Football Association proposed to 'continentalize' the Federation again (FIFA, “'Reorganisation”. Proposal presented at the FIFA Congress of Helsinki', October 30, 1952). These projects were obviously influenced by the cold war, as the 'Europe of football' consisted of merely 21 associations from the western part of the continent. A game between Hungary and Switzerland played in September in Bern showed perhaps a little moderation of attitude. Thus, the creation of an organization comprising all European countries was still doubtful at this stage. A number of problems needed to be resolved for the unified organization to come into being. However, certain actions taken by the South American members in early 1953 forced the European associations to change their strategy. Now, South America advocated reservations for Europeans in the future Executive Committees. This proposal might have looked paradoxical at first sight but it was an excellent tactic to reinforce the idea of a continentalization within FIFA, and finally help South America to secure places in the Executive Committee alongside Europe. At the same time, it allowed them to improve their relations with the European members after the bitter exchanges at the 1952 Congress.

Regarding the new modification of the statutes proposed by the Commission, the Uruguayan association expressed concern about the continents to the east and south of Europe being overlooked for positions in the Executive Committee (FIFA, Letter from A. Ramirez to K. Gassmann, January 30, 1953). This issue came up at the session of the Commission held on 6 and 7 March 1953, and it was there that two South American members formally asked for reservation of places for Europe, 'once and for all', in the Executive 
Committee. However, the proposal was not unanimously accepted; Seeldrayers and the vice-president Arthur Drewry rejected it. The opposite views 'could not be smoothed out' even after several rounds of discussions (FIFA, FIFA Study Commission, March 7, 1953). Nevertheless, the new situation was a step forward in favour of FIFA's continentalization. In fact, it nearly convinced European football administrators that creation of a continental 'Groupement' was not far off.

In June, Barassi and Rous met at Thommen's house in Basel to discuss this question. Ebbe Schwartz, the delegate of the Scandinavian associations was present too. The presence of these four important figures of European football reveals that the idea of a European organization was now afloat. No decision was reached in Basel but a new meeting with all the European associations was fixed before the next Congress. The meeting was held two days before the Extraordinary Congress (L'Equipe, November 15, 1953). Despite initial difficulties of conceptualizing a united front for European footballing nations, an agreement was seemed to be forthcoming. In fact, the European associations anticipated a big change in FIFA's structure and were ready to adapt to it. For the first time in the history of FIFA, European delegates spoke for a 'group of European associations' (FIFA, FIFA Congress, November 14-15, 1953). During the meeting other discussions were held, and for the first time with associations coming from across the Iron Curtain. The proactive South American associations engineered a compromise with European associations in the evening of the second day of the Congress. On the final day, Thommen passed the resolution to earmark two vice-presidencies and four member seats for Europeans (FIFA, FIFA Congress, November 14-15, 1953). Thus, European football administrators had finally accepted South American recommendations.

A majority of the Congress participants accepted the new ideas. In fact, only the Soviet Bloc associations were opposed to the proposed reorganization. Their expectation of more equality inside FIFA - the same wish to have underwrote their dealings with the International Olympic Committee (Parks 2014) - and empowerment of the emergent Asian and African countries were not fulfilled. This situation is interesting and shows that the Soviet Bloc was in fact isolated within FIFA because the other associations, particularly those from South America, did not concur with how the Soviet football leaders acted. For example, some month later, discussions between Argentina and Soviet Union about playing friendly games fell apart due to the way their respective national teams were composed. Soviet Union had no national team and it was still a club that represented the country (for instance Dynamo Moscow) on the international scene, which the Argentine football administrators refused to recognize as a 'national' team (France Football, June 8, 1955).

\section{The creation of a European group: following the South American model?}

The new article 17 of the FIFA statutes entailed the creation of a European group. Its fifth subparagraph stipulated that 'the members of the executive committee (vice-president and members) [would be] appointed by the national associations groups' (FIFA, FIFA Statutes, 1953 edition), which would be implemented during the first part of 1954 . Considering the context in which the decision was taken, gathering all the European football associations was not easy. Moreover, if the European associations finally found an arrangement to create an organization, should they realize a group dedicated only to elect European members at 
the FIFA's Executive Committee or something more ambitious that could develop synergies among European federations?

After the first discussion among members of the Permanent Commission (Barassi, Crahay and Delaunay) (FFF, Executive Committee meeting, January 11, 1954), a meeting was held in Paris in April 1954. Twenty-two Associations were present, including Czechoslovakia and Hungary from Eastern Europe. The delegates failed to come to an agreement (FIFA, Letter from E. Thommen to Jules Rimet, April 25, 1954) and fixed another meeting, to be held before the next FIFA Congress in June. Days later, Henri Delaunay, secretary of the Permanent Commission, wrote in a letter to the secretary of the GDR football association about the discussions and the possibility of a regroup. He proposed forming a confederation duplicating the South American model (GDR, Letter from H. Delaunay to the secretary of the GDR football association, April 20, 1954). He was confident of success as 22 associations had responded to his proposal (GDR, 'Answer of the National association to the questionnaire to create a European organisation', no data)

Finally, members of the Permanent Commission drew the first draft of the statutes proposing change and in a new meeting held in Basel on 15 June 1954, 25 (in fact 27, two officials were represented by others) European associations agreed to creation of a new group. The activities of the Soviet Bloc's members were not documented separately but they probably understood joining the new European group was necessary for them, a small group of ten associations, to be taken seriously. Moreover, the political transition in the Soviet Union following Stalin's death increased possibilities of sporting exchange between the East and the West. Following the end of the Korean War (1953), the Berlin conference (1954) in which the foreign ministers of the United States, Great Britain, France and the Soviet Union came together for the first time since 1948 evinced the wish to initiate new dialogues. Since football had already taken strides towards this direction, notably by the resumption of the International Cup, creation of a European group could be a timely intervention to connect countries culturally. Even though no western European organization had yet managed to cross the Iron Curtain, the 'two blocs' were linked in more ways than was acknowledged at that time (Hochscherf, Laucht, and Plowman 2010; Major and Mitter 2003).

During its first month, the organization, renamed UEFA in October 1954, was hardly an authoritative voice of football administration. For example, the idea of a European Championship it mooted in 1955 was rejected by the majority of the associations (Mittag and Legrand 2010). However, some members, notably the president Ebbe Schwartz wanted to consolidate the organization quickly. A first step was starting the European Champion Clubs' Cup, an idea first proposed by Gabriel Hanot, editor of the Parisian newspaper L'Equipe (Vonnard 2014), modelled after the South American Championship of Champions held in Chile in 1948. This gave more legitimacy and new stakes to the organization (Vonnard 2016). Secondly, UEFA needed to consolidate its financial resources. A possibility was to ask FIFA to remit half of the percentage (2\%), equivalent to what the South American confederation earned, that it received from games played among European countries. UEFA-FIFA correspondences show that this was discussed for one year and caused tensions between the two organizations. Finally, Ernst Thommen, now vice-president of FIFA and president of its Financial Committee, brokered a deal for FIFA to give UEFA (and other confederations, such as the Asian confederation created in 1956) the same right as the South American confederation. 
Creation of a championship of European nations was a strong motivation for people ranging from Gustav Sebes (Hungary), one of the new generation of open-minded football administrators from eastern Europe, to the son of Henri Delaunay, Pierre, the new secretary of UEFA, succeeding his father in 1955. They considered it important to develop the structure of UEFA and also to create football tournaments and stronger connection between European associations. After numerous discussions in the 1957 and 1958 UEFA Congress (UEFA, General Assemblies, 1957 and 1958), a majority, influenced by Copa America, decided to create a European tournament that begun in 1959 (final round took place in 1960) (UEFA, UEFA General Assembly, June 4, 1958). Hence, from 1954 to 1958, the South American confederation directly influenced the decisions taken by European football administrators, leading to the creation of UEFA and the European Nations Cup. At the end of the decade, UEFA started to become an important actor in FIFA as the representative of European football and a powerful counterpart to the South American confederation. These new actors in global football augured a new age in the history of FIFA.

\section{Conclusion: understanding transnational influence in the organization of football}

The creation of UEFA was important for European football and could be seen as a step forward to football's globalization in the post-war period, compared to the inter-war years when regional loyalties outweighed transnational and transcontinental connections (Dietschy 2015). In fact, by organizing competitions (European Cups for clubs, European championship of nations, tournaments for youth), passing regulations (for example about broadcasting) and preparing even courses for referees and trainers, UEFA became the legitimate organization for control of European football in the 1960-70s. By helping to develop better network among associations, it played an important part in the 'Europeanisation of football' (Vonnard, Quin, and Bancel 2016) during the cold war and beyond. Its popularity and effective management of sporting exchange through continental competitions have made some authors ponder about its role in the establishment of a European identity (Sonntag 2008). More recently, others have touched upon its role in the creation of 'European sites of memory' (Groll 2014).

This article has explored from a global perspective the influence of the South American model of football organization on European football administration. The ascension of the South American confederation within FIFA undoubtedly inspired the new generation of European administrators in the beginning of the 1950s. Thereafter, the confederation was seen as a model, firstly to integrate European football associations, and secondly for a reorganization of FIFA. It is also important to notice what historians specialized in global history have called the 'back effect' (Douki and Minard 2007). UEFA's undertakings in football governance from the mid-1950s began to be perceived as a model for administrators from Asia, Africa and even South America. At the end of 1950s, South America followed the European example when they put in place a club football competition, the Copa Libertadores. Hence, as Eisenberg (2011) has already indicated, knowledge of transcontinental connections could be really helpful to understand the development of football structures all over the world. 


\section{References}

Alabarces, Pablo. 2002. Soccer and Nations. The Image of the Nations through Soccer in the Argentina's newspapers. Buenas Aires: Prometeo Libros.

Diaz Alejandro, Carlos F. 1984. "The 1940s in Latin America." In Economic Structure and Performance, edited by Moshe Syrquin, Lance Taylor, and Larry E. Westphal, 341-362. New York, NY: Harcourt.

Archambault, Fabien. 2012. "The difficult development of the Europeanization of Football during the 1950's". In Making Europe. Cultural Aspects of European integration (1957-2007), edited by Pamela Anastasio and Charles Bossu, 85-96, Rome: Unione Internazionale degli Istituti di Archeologia.

Archambault, Fabien. 2014. "The continent of football." Cahiers des Amériques latines 74: 15-35.

Armus, Diego, and Stefan Rinke. 2014. The History of Argentina, Brasillian and Uruguyan football. Frankfurt am Main: Vervuert.

Barcelo, Laurent. 2004. "Europe of 52.... The Union of European Football Associations (UEFA)." Gueres mondiales et conflits contemporains 228 (4): 119-133.

Beck, Peter J. 2000. "Going to War, Peaceful Co-existence or Virtual Membership? British Football and FIFA, 1928-46." The International Journal of the History of Sport 17 (1): 113-134.

Berthoud, Jérôme, Grégory Quin, and Philippe Vonnard. 2016. The Swiss Football. From the Pioneers to Professionnals. Lausanne: PPUR.

Breuil, Xavier, and Constantin Pompiliu-Nicolae. 2015. "The Balkan Cup as a Vector of European Integration, 1929-1994." Sport in History 35 (4): 591-603.

Cavallaro, Maria Elena. 2009. "The Spanish European Integration: The First Steps of a Long Journey." In The Two Europes, edited by Michele Affinito, Guia Migani, and Christian Wenkel, 149-163. Brussels: Peter Lang.

Charitas, Pascal. 2015. "Imperialisms in the Olympics of the Colonization in the Postcolonization: Africa into the International Olympic Committee, 1910-1965." The International Journal of the History of Sport 32 (7): 909-922.

Collins, Tony. 2015. The Oval World. A Global History of Rugby. London: Bloomsbury.

Compagnon, Olivier. 2013. Goodbye Europe. The Latin America and the First World War. Paris: Fayard.

Compagnon, Olivier. 2015. "Beyond the War? The Latin Americas.” In, The Global-War. First Volume, edited by Alya Aglan and Robert Frank, 565-598, Paris: Gallimard.

Davies, Darién J. 2000. "British Football with a Brazilian Beat: The Early History of a National Pastime (1894-1933)." In English-speaking Communities in Latin America, edited by Oliver Marshall, 261284. London: Institute of Latin American Studies.

Dichter, Heather. 2013. "Kicking Around International Sport: West Germany's Return to the International Community through Football." The International Journal of the History of Sport 30 (17): 2031-2051.

Dichter, Heather, and Andrew Johns, eds. 2014. Diplomatic Games: Sport, Statecraft, and International Relations since 1945. Lexington, KY: University Press of Kentucky.

Dietschy, Paul. 2006. "Football and Total War: The Case of the Second World War." In The Football in our Societies, edited by Yvan Gastaut and Stéphane Mourlane, 159-173. Paris: Autrement.

Dietschy, Paul. 2010. History of Football. Paris: Perrin.

Dietschy, Paul. 2013. "Making Football Global? FIFA, Europe, and the Non-European Football World, 1912-74." Journal of Global History 8: 279-298.

Dietschy, Paul. 2015. "Did a "Europe of football” Exist in the 1930's?" Sport in History 35 (4): 515-530.

Dietschy, Paul, Yvan Gastaud, and Stéphane Mourlane. 2006. A Political History of the football's Worlds Cups. Paris: Perrin.

Douki, Caroline, and Philippe Minard. 2007. "Global History, Connected History: A Change of Scales in Historiography?" Revue d'histoire moderne et contemporaine 54 (5): 7-21.

Dumont, Juliette. 2009. The Brazil and the International Institut of Intellectual Cooperation. 1924-1946. A Tool of Cultural Diplomacy. Paris: Éditions de l'IHEAL.

Dumont, Juliette. 2012. "From Intellectual Cooperation to Cultural Diplomacy: The Brazil During the Interwar period." Caravelle. Cahiers du monde hispanique et luso-brésilien 99: 217-238.

Eisenberg, Christiane. 2011. “Towards a New History of European Sport?” European Review 19 (4): $617-622$. 
Eisenberg, Christiane, Pierre Lanfranchi, Tony Mason, and Alfred Wahl. 2004. 100 Years of Football: The FIFA Centennial Book. London: Weidenfeld and Nicolson.

Fontes, Paulo, and Bernardo Buarque de Hollandia. 2014. The Country of Football: Politics, Popular Culture and the Beautiful Game in Brazil. London: C. Hurst \& Co.

Giulianotti, Richard, and Roland Robertson. 2009. Globalization and Football. London: Sage.

Gleaves, John, and Thomas M. Hunt. 2015. A Global History of Doping in Sport. London: Routledge. Goldblatt, David. 2006. The Ball Is Round: A Global History of Soccer. London: Viking.

Grainey, Timothy. 2012. Beyond Bend It Like Beckham. The Global Phenomenon of Women's Soccer. Lincoln, NE: University of Nebraska Press.

Groll, Michael. 2014. "UEFA Football Competition as European Site of Memory - Cups of Identity." In European Football and Collective Memory, edited by Wolfram Pyta and Nils Havemann, 63-84, Basingstoke: Palgrave Macmillan.

Gygax, Jérôme. 2012. Olympism and Cold War. The Prize of the US Victory. Paris: L'Harmattan.

Helleiner, Eric. 2014. The Forgotten Foundations of Bretton Woods: International Development and the Making of the Postwar Order. New York, NY: Cornell University Press.

Hémeury, Lucie. 2014. "Between Stands and Pitch. The Sportives Cultures of the Argentinians Political Leaders 1880-1990.” Histoire@Politique 23 (2): 97-122.

Hochscherf, Tobias, Christoph Laucht, and Andrew Plowman. 2010. Divided, but Not Disconnected: German Experiences of the Cold War. New York, NY: Berghahn Books.

Homburg, Heidrun. 2008. "Financing World Football: A Business History of the Fédération Internationale de Football Association (FIFA)." Zeitschrift für Unternehmensgeschichte 53 (1): 33-69.

Klein, Alan. 2007. “Towards a Transnational Sports Studies.” Sport in Society 10 (6): 885-889.

Kowalski, Ronald, and Dilwyn Porter. 2003. "England's World Turned Upside Down? Magical Magyars and British Football." Sport in History 23 (2): 27-46.

L'Hoeste, Fernández Hector, McKee Irwin, Robert, and Juan Poblete. 2015. Sports and Nationalism in Latin/O America. Basingstoke: Palgrave MacMillan.

Laborie, Léonard. 2010. Networking Europe. The France and the International Cooperation in Postal and Telecommunications (1850-1950). Brussels: Peter Lang.

Loth, Wilfried. 2004. Europe, the Cold War and Coexistence, 1953-1965. London: Routledge.

Major, Patrick, and Rana Mitter. 2003. "East is East and West is West? Towards a Comparative Sociocultural History of the Cold War." Cold War History 4 (1): 1-22.

Malz, Arié, Rohdewald, Stefan, and Stefan Wiederkehr. 2007. Sport Between East and West. For an History of Sport in Eastern Europe. 19 and 20 Century. Osnabrück: Fibre Verlag.

Marston, Kevin. 2015. “A Lost Legacy of Fraternity? The Case of European Youth Football.” In Routledge Handbook of Sport and Legacy: Meeting the Challenge of Major Sporting Events, edited by Richard Holt and Dino Ruta, 176-188. London: Routledge.

Mason, Tony. 1995. Passion of the People? Football in South America. London: Verso.

Mittag, Jürgen. 2015. "Negociating the Cold War? Perspectives in Memory Research on UEFA, the Early European Football Competitions and the European Nations Cups." In European Football and Collective Memory, edited by Wolfram Pyta and Nils Havemann, 40-63. Basingstoke: Palgrave Macmillan.

Mittag, Jürgen, and Benjamin Legrand. 2010. “Towards a Europeanization of Football? Historical Phases in the Evolution of the UEFA Football Championship." Soccer \& Society 11 (6): 709-722.

Mittag, Jürgen, and Jörg-Uwe Nieland. 2013. "Searching Europe: UEFA and EBU as Vector of Europeanization of sport." In Friend or Foe? Sport Between East and West During the Cold Wars, edited by Christoph Bertling and Evelyn Mertin, 208-229. Gütersloh: Medienfabrik Gütersloh.

Parks, Jenifer. 2007. "Verbal Gymnastics: Sports, Bureaucracy, and the Soviet Union's Entrance into the Olympic Games, 1946-1952." In East Plays West: Sport and the Cold War, edited by Steven Wagg and David Andrews, 27-44. London: Routledge.

Parks, Jenifer. 2014. "Welcoming the 'Third World'. Soviet Sport Diplomacy, Developing Nations and the Olympic Games”. In Diplomatic Games: Sport, Statecraft, and International Relations since 1945, edited by Heather Dichter and John Andrew, 85-114, Lexington, KY: University Press of Kentucky. 
Péchoux, Pierre-Yves. 2004. "Which Frontiers for Europe?” In Thinking on the Frontiers of Europe. From 19 to 20 Century. Historical Approaches, edited by Gilles Pécout, 119-136. Paris: PUF.

Quin, Grégory. 2013. “The International Cup. 1927-1938. A Forgotten International Competition” Stadion. Revue Internationale d'Histoire du Sport 37 (2): 285-304.

Racine, Nicole. 2008. "The International Associations of Writers During the Cold War: The Exemple of French PEN club." In Despite Europe, 1945-1990, edited by Antoine Fleury and Lubor Jilek, 139-152. Brussels: Peter Lang.

Rider, Toby. 2011. "The Olympic Games and the Secret Cold War: The U.S. Government and the Propaganda Campaign against Communist Sport, 1950-1960.” Thesis, Western Ontario University.

Rothenbühler, Rudolph. 1979. UEFA. 25 Years. Berne: UEFA.

Sbetti, Nicola. 2016. "Quest for Legitimacy: the Road to Redemption of Italian Football in Europe after the Second World War (1943-1949)." In Building Europe with the Ball: Turning Points in the Europeanization of Football. 1905-1995, edited by Philippe Vonnard, Grégory Quin and Nicolas Bancel. 101-119. Oxford: Peter Lang.

Senyuva, Özgehan, and Sevecen Tunç. 2015. “Turkey and the Europe of Football.” Sport in History 35 (4): 567-579.

Singaravélou, Pierre, and Julien Sorez. 2010. The Sport's Empire. An History of the Cultural Globalization (19 and 20 Centuries). Paris: Belin.

Sonntag, Albrecht. 2008. "Shared Passion, Ambiguous Identities. European Stakes of Contemporary Football." Politique européenne 26 (3): 191-209.

Sudgen, John, and Alan Tomlinson. 1997. "Global Power Struggles in World Football: FIFA and UEFA, 1954-74, and Their Legacy." The International Journal of the History of Sport 14 (2): 1-25.

Svetozar, Rajak. 2011. Yugoslavia and the Soviet Union in the Early Cold War: Reconciliation, Comradeship, Confrontation, 1953-1957. Londres: Routledge.

Taylor, Matthew. 2006. "Global players? Football, Migration and Globalization, c. 1930-2000." Historical Social Research 31 (1): 7-30.

Taylor, Matthew. 2013. "Editorial - Sport, Transnationalism, and Global History." Journal of Global History 8 (2): 199-208.

Taylor, Matthew. 2016. “English Football and 'the Continent' Reconsidered, 1919-1960.” In Building Europe with the Ball: Turning Points in the Europeanization of Football. 1905-1995, edited by Philippe Vonnard, Grégory Quin, and Nicolas Bancel. 75-97. Oxford: Peter Lang.

Thorp, Rosemary. 1994. "The Latin American Economies in the 1940s." In Latin America in the 1940s. War and Postwar Transition, edited by David Rock, 41-58. Berkeley: University of California Press.

Tiesler, Nina Clara, and Joao Nuno Coelho. 2008. Globalized Football: Nations and Migration, the City and the Dream. London: Routledge.

Vonnard, Philippe. 2014. "A Competition That Shook European Football: The Origins of the European Champion Clubs' Cup, 1954-1955.” Sport in History 34 (4): 595-619.

Vonnard, Philippe. 2016. "How did UEFA Govern the European Turning Point in Football? UEFA, the European Champion Clubs' Cup and the Inter-Cities Fair's Cup Projects (1954-1959).” In Building Europe with the Ball: Turning Points in the Europeanization of Football. 1905-1995, edited by Philippe Vonnard, Grégory Quin and Nicolas Bancel, 165-186. Oxford: Peter Lang.

Vonnard, Philippe, Quin, Grégory, and Nicolas Bancel. 2016. Building Europe with the Ball: Turning Points in the Europeanization of football. 1905-1995. Oxford: Peter Lang.

Wahlig, Henry. 2010. A Goal for the World. The German Football and the FIFA. 1945-1950. Göttingen: Verlag die Werksatt. 